\title{
Late Pleistocene mountain glaciation in Alaska: key chronologies
}

\author{
JASON P. BRINER ${ }^{*}$ and DARRELL S. KAUFMAN ${ }^{2}$ \\ 1 Geology Department, University at Buffalo, Buffalo, New York, USA \\ ${ }^{2}$ Department of Geology, Northern Arizona University, Flagstaff, Arizona, USA
}

Briner, J. P. and Kaufman, D. S. 2008. Late Pleistocene mountain glaciation in Alaska: key chronologies. J. Quaternary Sci., Vol. 23 pp. 659-670. ISSN 0267-8179. Received 2 July 2007; Revised 17 April 2008; Accepted 17 April 2008

\begin{abstract}
Moraine sequences of mountain glaciers can be used to infer spatial and temporal patterns of climate change across the globe. Alaska is an accessible high-latitude location in the Northern Hemisphere and contains a rich record of alpine glaciation. Here, we highlight the key chronologies from three mountain ranges in Alaska that reveal the timing and spatial extent of Late Pleistocene glaciation, and pay particular attention to age of the penultimate glaciation. The most extensive glacier advance of the last glaciation occurred prior to the last global glacial maximum. Cosmogenic exposure ages from moraine boulders in three sites spanning $800 \mathrm{~km}$ indicate that this penultimate advance most likely culminated during marine isotope stage (MIS) 4 or early MIS 3. During MIS 2, more limited glacier expansion generated multiple moraines that span from prior to the global Last Glacial Maximum (LGM) through the Lateglacial period. Glaciers retreated from their terminal positions ca. 27-25 ka in arctic Alaska and ca. 22-19 ka in southern Alaska. Moraines in at least two ranges date to $12-11 \mathrm{ka}$, indicating a glacial advance during the Younger Dryas period. Reconstructed equilibrium-line altitudes of both penultimate and MIS 2 glaciers were lowered only 300-600 m much less than elsewhere in the Americas. Alaska is documented to have been more arid during MIS 2, perhaps due in large part to the exposure of the Bering-Chukchi platform during eustatic sea-level lowering. The restricted ice extent is also consistent with the output of climate models that simulate a lack of significant summer cooling. Copyright (C) 2008 John Wiley \& Sons, Ltd.
\end{abstract}

KEYWORDS: Alaska; glaciation; Late Pleistocene; chronology; mountain glacier.

\section{Introduction}

Alaska is often characterised as a land of extremes, and the same applies to its glacial geology. The state presently hosts the largest valley glaciers in North America, yet during the Pleistocene it encompassed the largest unglaciated expanse on the continent. Presently (ca. 1970), glaciers cover about $75000 \mathrm{~km}^{2}$ of the state and are distributed among 14 centres of glacierisation (Molnia, 2007). During the global Last Glacial Maximum (LGM), the area of glacier cover expanded by tenfold, to about $727800 \mathrm{~km}^{2}$ (Kaufman and Manley, 2004), and encompassed several lower-elevation massifs that are not glaciated today. The vast majority of this expansion involved glaciers that surround the Gulf of Alaska. This amalgamation of coalescent ice caps and piedmont lobes formed the northwestern extension of the Cordilleran Ice Sheet (Hamilton and Thorson, 1983). Like their modern counterparts, these glaciers benefited from a proximal source of moisture, a persistent

* Correspondence to: J. Briner, Geology Department, University at Buffalo, Buffalo, NY 14260, USA.

E-mail: jbriner@buffalo.edu

Contract/grant sponsor: NSF; contract/grant numbers: OPP-9977972; OPP9977974. atmospheric circulation pattern that drove moist air inland, and adiabatic cooling associated with the extraordinary mountainous terrain. In contrast, the interior part of the state was never extensively glaciated. The Cordilleran ice formed an effective barrier to moisture derived from the Gulf of Alaska and prevailing southwesterly winds dried as sea ice expanded and global sea level lowered, exposing the Bering-Chukchi platform. The only significant centres of glacier growth beyond the Cordilleran Ice Sheet were the Brooks Range in arctic Alaska and the Ahklun Mountains in the south-west part of the state.

Because most of Alaska was never glaciated, mountain glaciers freely expanded onto unglaciated piedmonts, where they left moraines dating to multiple glaciations. The ages of some moraines are known where they have been correlated with radiometric ages on organic matter or volcanic products interbedded with outwash (Hamilton, 1994). With the advent of cosmogenic exposure dating, direct ages on Late Pleistocene moraine stabilisation have recently been obtained from several mountain ranges in Alaska (Briner et al., 2005). The growing database of tephra marker beds has further refined the ages of glacier deposits (Begét and Keskinen, 2003).

In this paper, we summarise the key Late Pleistocene mountain glacier chronologies currently available in Alaska. This is the first detailed review of mountain glacier chronology in Alaska since Hamilton (1994). It benefits from a recent 


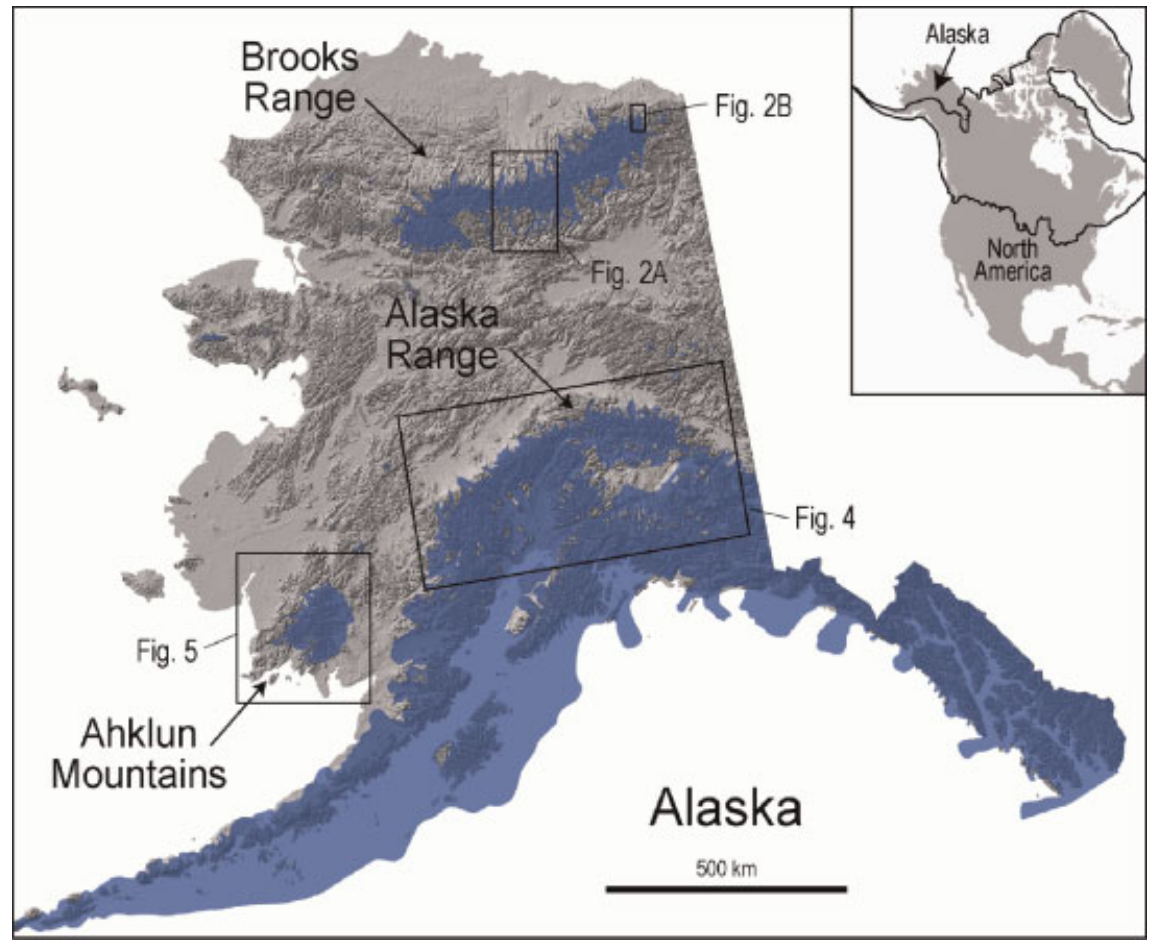

Figure 1 Alaska, showing the extent of glacier ice during the late Wisconsin (from Kaufman and Manley, 2004; available online by Manley and Kaufman, 2002) and areas discussed in this paper where moraine sequences spanning the Late Pleistocene have been well dated. Inset shows extent of coalescent ice sheets over North America during the LGM (from Dyke et al., 2002). This figure is available in colour online at www.interscience. wiley.com/journal/jqs

compilation of late Wisconsin state-wide glacier extents (Kaufman and Manley, 2004) and a recent summary of Quaternary alpine glaciation in Alaska (Kaufman et al., 2004). The most complete and robust chronologies are from the Brooks Range (northern Alaska), the Alaska Range (central Alaska) and the Ahklun Mountains (southwestern Alaska). Some Late Wisconsin moraines are dated in other parts of Alaska, for example on the Alaska Peninsula (Mann and Peteet, 1994; Stilwell and Kaufman, 1996) and the Kenai Peninsula (Reger and Pinney, 1996). Here, we focus on the sequences that include moraines deposited during both the late Wisconsin and the penultimate glaciations so the relative extent of glaciers through the Late Pleistocene can be assessed. In particular, we use this compilation of recently published chronologies to address a long-standing debate centred on the age of the penultimate glaciation in Alaska.

The ages of Late Pleistocene glacial features are primarily based on either cosmogenic exposure dating (mostly using ${ }^{10} \mathrm{Be}$ ) or ${ }^{14} \mathrm{C}$ dating. Cosmogenic exposure ages from surface boulders on moraines date the glacier retreat and subsequent stabilisation of the landform. Briner et al. (2005) discussed alternative interpretations of clusters of cosmogenic exposure ages from moraine boulders in Alaska and concluded that the oldest ages in a cluster generally yielded the best agreement with independent age information where available. Because this method relies heavily on just the single oldest age (excluding obvious outliers with inheritance; e.g. those that are $>2 \sigma$ from the average of the others), Briner et al. (2005) reported moraine ages as the range between the oldest age and the average age (excluding outliers). All cosmogenic exposure ages reported here are also presented in this way. The uncertainty listed following the average age represents the $1 \sigma$ variability among boulders. Additional uncertainties result from shielding effects related to snow cover and rock surface erosion rates. All cosmogenic exposure ages reported here are unmodified from their original publications, and in all cases are based on the same isotope production rates. Although there are differences in other calculations, such as altitude scaling, shielding and erosion effects, these should be relatively minor ( $<10 \%$ of the age). In contrast to exposure ages, ${ }^{14} \mathrm{C}$ ages generally bracket the timing of glacier fluctuations and must be interpreted in the context of the morphostratigraphic position of the sample. All ${ }^{14} \mathrm{C}$ ages have been calibrated to calendar years using CALIB (v5) (Stuiver and Reimer, 1993) and are reported in cal. ka BP (hereafter ' $k a$ '). Most ages are rounded or should be considered approximate at the millennium scale, even where this is not stated explicitly.

\section{Brooks Range}

The Brooks Range (Fig. 1) forms the northernmost drainage divide in north-west North America. It spans $\sim 1000 \mathrm{~km}$ across northern Alaska from the Alaska-Yukon border to the Chukchi Sea. Summit elevations increase eastward, exceeding $2700 \mathrm{~m}$ above sea level (a.s.l.) in the north-east. Today, the range encompasses hundreds of small, subpolar valley glaciers sheltered behind the highest north-facing cirque headwalls (Calkin and Ellis, 1980). The Brooks Range was the largest centre of Quaternary glaciation in Alaska outside of the Cordilleran Ice Sheet. Glaciers expanded to the north and south from the central crest and were mostly composed of long, complex and interconnected valley glaciers.

The extensive suite of moraines in the Itkillik River area, central Brooks Range, serves as the reference locality for Late Pleistocene glaciations of the Brooks Range (Fig. 2; Hamilton, 1986a). Moraines are subdivided into the Itkillik I (older) and Itkillik II (younger) advances (Hamilton and Porter, 1975; Fig. 3). Glaciers expanded up to $40 \mathrm{~km}$ north of the northern range front during the Itkillik I phase, and up to $25 \mathrm{~km}$ north of 


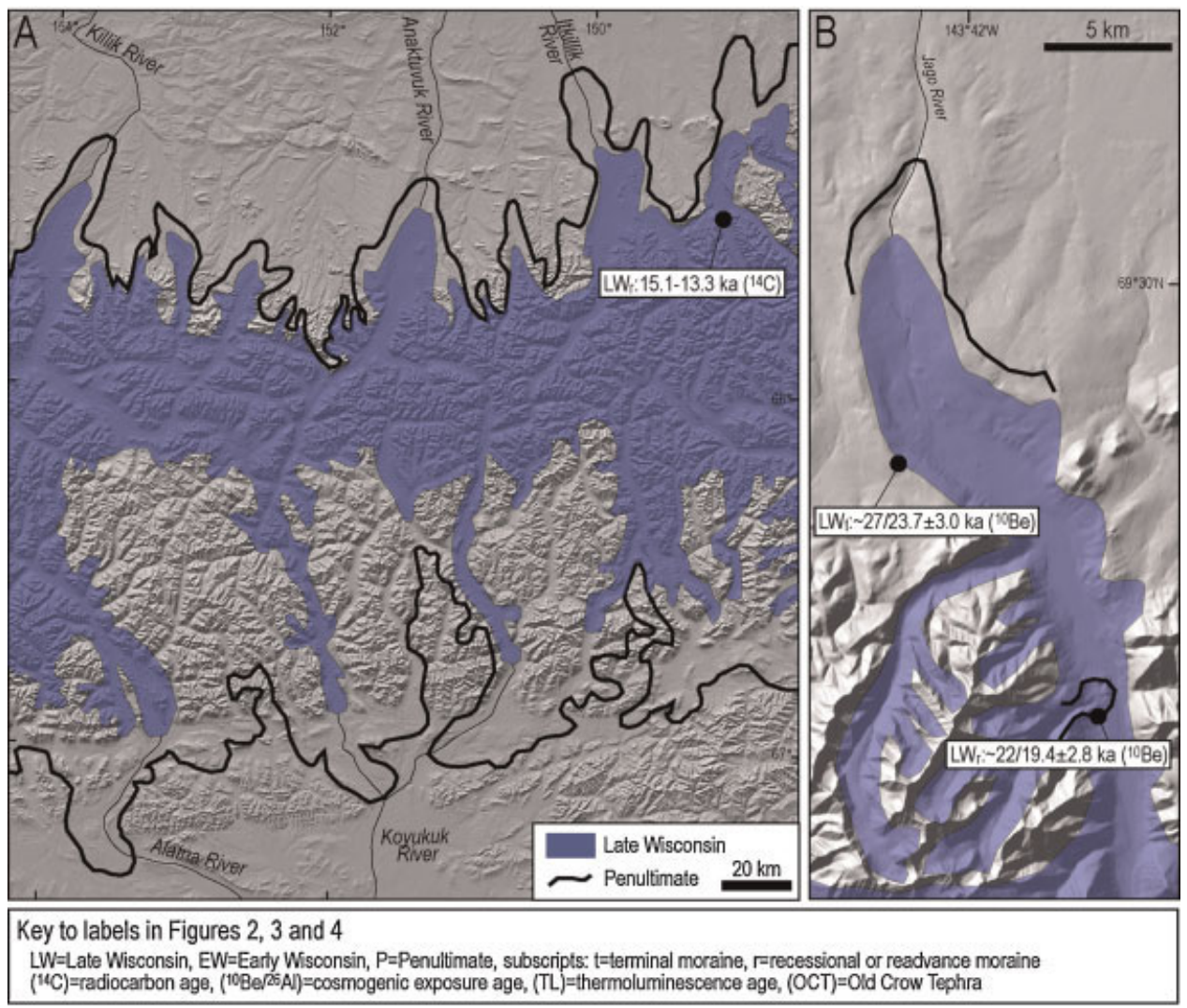

Figure 2 (A) Central and (B) northeastern Brooks Range showing the extent of glaciers during the penultimate and late Wisconsin glaciations with locations of key ages. Map areas are shown in Fig. 1. This figure is available in colour online at www.interscience.wiley.com/journal/jqs

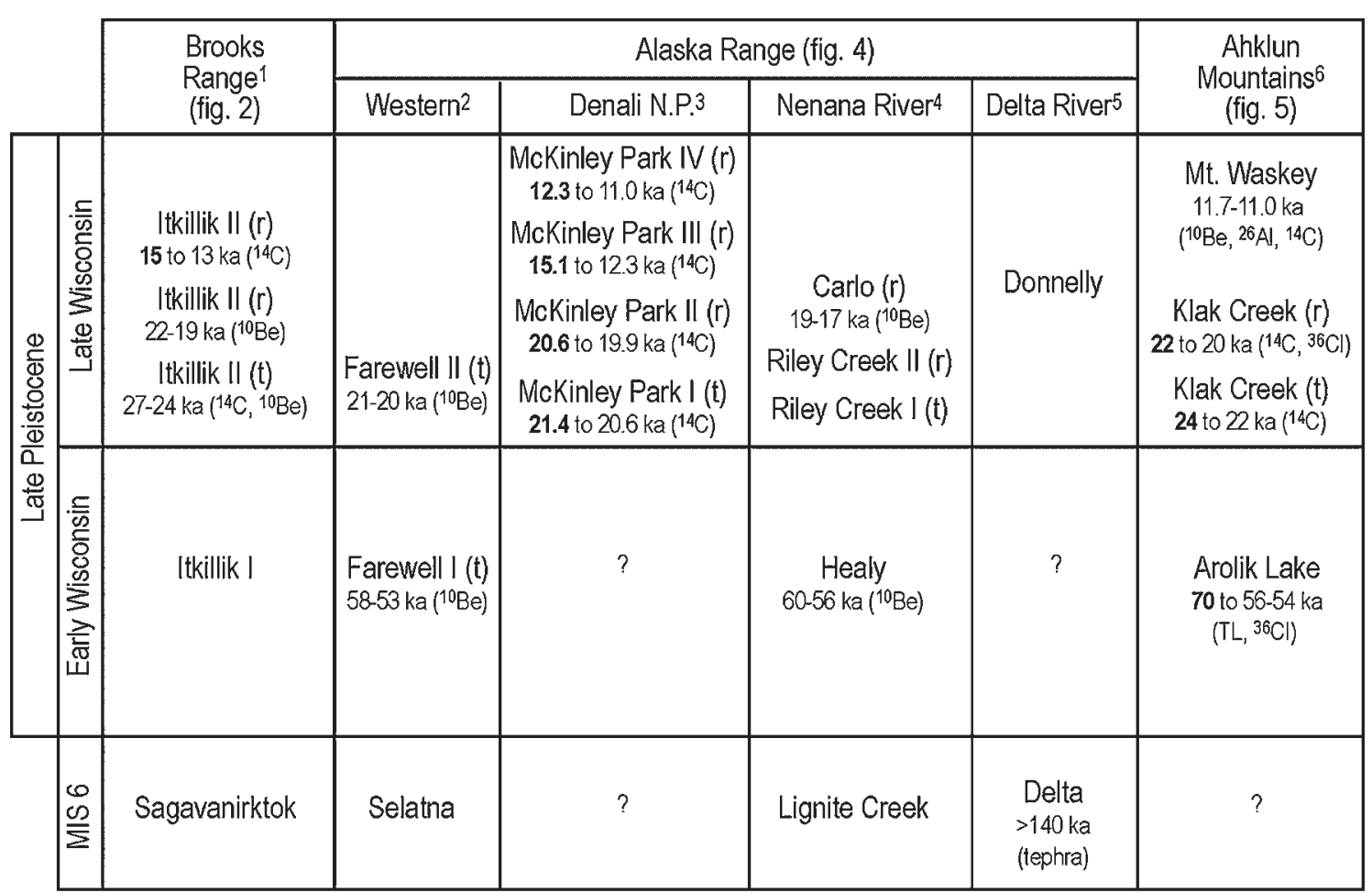

Key: $(t)=$ terminal moraine, $(r)=$ readvance or recessional moraine, bold=maximum age, plain font=minimum age.

References for chronolgies: 1: Hamilton, 1982, 2003; Balascio et al., 2005a; Briner et al., 2005. 2: Briner et al., 2005.

3: Ten Brink and Waythomas, 1985; Werner et al., 1993; Child, 1995. 4: Dortch, 2006. 5: Begét and Keskinen, 2003.

6: Briner et al., 2001, 2002; Kaufman et al., 2003b).

Figure 3 Correlation chart showing approximate ages and local nomenclature for glacial intervals in areas discussed in the text. The dating method that the age constraints are based on is listed 
the range front during the Itkillik II phase (Hamilton, 1982). Recent detailed mapping in the Itkillik River area resulted in further subdivision of the glacial deposits (Hamilton, 2003). The Itkillik I glaciation was subdivided into two phases based on differences in postglacial modification of moraines. We refer to the moraines deposited during the Itkillik I glaciation as the 'penultimate' moraines. The Itkillik II (late Wisconsin) glaciation was also subdivided into two primary phases, including a maximum advance and a later readvance. Each of these phases of the Itkillik II glaciation is represented by two distinct moraines in the Itkillik River area (Hamilton, 2003).

Two phases of the Itkillik I advance recognised in the central Brooks Range are older than non-finite ${ }^{14} \mathrm{C}$ ages of $53 \mathrm{ka}$, and are believed to be younger than the last interglacial maximum (marine isotope stage (MIS) 5e; Hamilton, 1994). In the Noatak basin of the western Brooks Range, two separate advances are younger than the $140 \mathrm{ka}$ Old Crow tephra and older than 36$34 \mathrm{ka}$ (Hamilton, 2001). There are no published luminescence or cosmogenic exposure ages on Itkillik I (penultimate) drift in the Brooks Range.

The subsequent Itkillik II glaciation in the Brooks Range (Fig. 2) is bracketed in both the central (Hamilton, 1982) and western Brooks Range (Hamilton, 2001) between 30 and $13 \mathrm{ka}$. Numerous ${ }^{14} \mathrm{C}$ ages have been reported from Itkillik II outwash in the Koyakuk River area on the south side of the range (Hamilton, 1982). The outwash has been correlated with moraines upvalley and thereby has been used to infer the timing and position of glacier fluctuations in the central Brooks Range. The maximum Itkillik II glaciation occurred between about 27 and $25 \mathrm{ka}$, and was followed by an advance almost as extensive as the first after $23 \mathrm{ka}$. Alluviation of outwash streams seems to have ceased by $15 \mathrm{ka}$ (Hamilton, 1982). In the north-central Brooks Range, where a detailed sequence of Itkillik I and II moraines has been mapped in the Itkillik River area (Fig. 2(A)), a readvance at the northern range front led to rapid alluviation of a moraine-dammed valley from 15.1 to 13.3 ka (Hamilton, 2003). The broad troughs between the range front and the cirques contain a suite of end moraines, but they have yet to be dated.
The outer two ridges of a prominent nested-moraine sequence in the Jago River valley, northeastern Brooks Range (Fig. 2(B)) have been correlated with the Itkillik II glaciation, and have been dated with ${ }^{10} \mathrm{Be}$ on moraine boulders (Balascio et al., 2005a). The Itkillik II terminal moraine in the Jago River valley, which projects $12 \mathrm{~km}$ to the north of the range front, stabilised between 27 and $23.7 \pm 3.0 \mathrm{ka}$. A prominent end moraine $8 \mathrm{~km}$ upvalley from the range front, which was deposited at the mouth of a tributary valley that contains the Hubly Glacier, stabilised between 22 and $19.4 \pm 2.8 \mathrm{ka}$ (Balascio et al., 2005a).

Equilibrium-line altitudes (ELAs) have been reconstructed for smaller, topographically constrained Itkillik II glaciers across the Brooks Range using the accumulation area ratio method (Balascio et al., 2005b). ELAs rise from west to east at $1.4 \mathrm{~m} \mathrm{~km}^{-1}$, and are highest in the northeastern sector of the range, where the highest summits presently support the largest glaciers in the range. The Itkillik II ELA surface is generally parallel to the modern, and is about $250 \mathrm{~m}$ lower on average (Balascio et al., 2005b). ELAs for Itkillik I glaciers are difficult to reconstruct because most glacier ice was interconnected and divides demarking their source areas are poorly defined. During the Itkillik I glaciation, ice was tens of kilometres more extensive than during the Itkillik II. Considering the low gradient of the valleys, however, ELAs were likely only a few tens of metres lower during the Ikillik I glaciation than Itkillik II.

\section{Alaska Range}

The Alaska Range (Fig. 4) was occupied by the western extension of the Cordilleran Ice Sheet during the Late Pleistocene. In some portions of the range, the ice comprised a series of interconnected ice fields. Along the west and northern flanks of the Alaska Range, ice formed smaller, independent valley glacier systems. Moraine sequences in

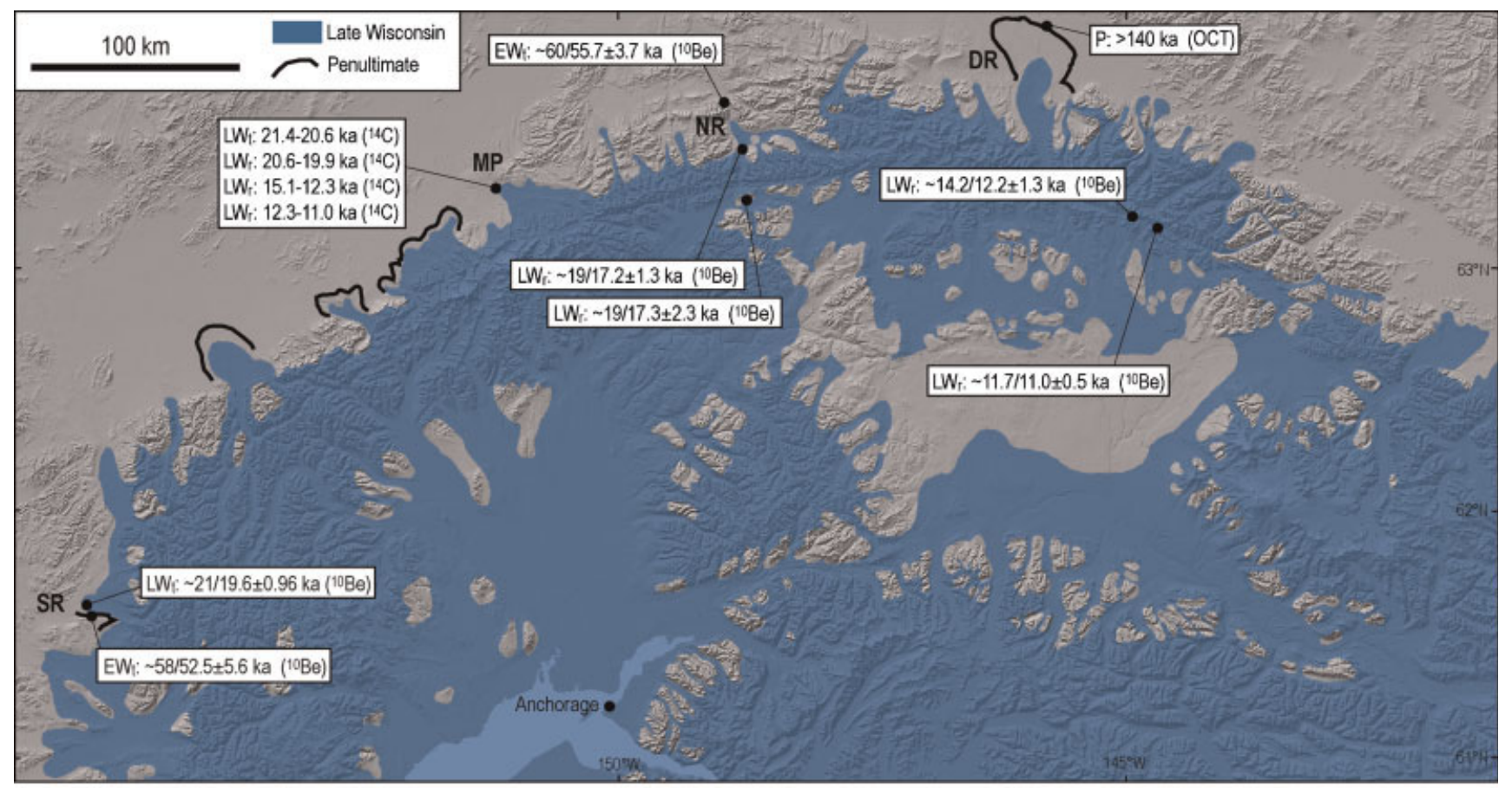

Figure 4 North Alaska Range showing the extent of glaciers during the penultimate and late Wisconsin glaciations with locations of key ages. Map area shown in Fig. 1; explanation of map abbreviations in Fig. 2. This figure is available in colour online at www.interscience.wiley.com/journal/jqs 
valleys across the northern Alaska Range typically consist of at least two major drift units (early and late Wisconsin), each deposited during multiple phases (e.g., Ten Brink and Waythomas, 1985; Kline and Bundtzen, 1986; Thorson, 1986). Several valleys within the Alaska Range have a long history of glacial-geological research and a local nomenclature of glacial deposits (Hamilton, 1994).

The age of the penultimate drift in the Alaska Range is best constrained in three localities. A moraine sequence deposited along the Delta River valley beyond the northern Alaska Range front (Fig. 4) constitutes the reference locality of the Donnelly (late Wisconsin) and Delta (penultimate) glaciations (Péwé, 1953; Fig. 3). An outwash terrace that grades to the Delta moraine is overlain by the Old Crow Tephra (140 ka), suggesting that it is older than the Late Pleistocene (Begét and Keskinen, 2003). A more detailed moraine sequence in the Nenana River valley, north-central Alaska Range (Fig. 4; Wahrhaftig, 1958; Thorson, 1986) was the focus of a recent exposure-dating study. Dortch (2006) obtained nine ${ }^{10} \mathrm{Be}$ ages on boulders from landforms created during the Healy glaciation, which is thought to be the equivalent to the moraine deposited in the Delta River valley during the Delta glaciation (Fig. 3; Hamilton, 1994). The Healy landforms, excluding one young outlier, range between 60 and $55.7 \pm 3.7 \mathrm{ka}$ (Dortch, 2006). At a third locality, in the Swift River valley of the western Alaska Range (Fig. 4), Briner et al. (2005) mapped a sequence of moraines and correlated them with the Farewell I (penultimate) and Farewell II (late Wisconsin) moraines in the nearby Farewell region (Fig. 3; Kline and Bundtzen, 1986). The Farewell I equivalent moraine, dated by four ${ }^{10} \mathrm{Be}$ ages, stabilised between 58 and $52.5 \pm 5.6 \mathrm{ka}$ (Briner et al., 2005).

The most robust ${ }^{14} \mathrm{C}$ chronologies for late Wisconsin moraines in the Alaska Range come from Denali National Park, the Nenana River valley (Fig. 4) and a few additional valleys. In the McKinley (Denali National Park) and Nenana River valleys, a fourfold sequence of late Wisconsin moraines is well dated, and Porter et al. (1983) provide the most detailed review of the timing of late Wisconsin glacier fluctuations. Several maximum-limiting ${ }^{14} \mathrm{C}$ ages constrain the initial late Wisconsin advance to sometime after 27 ka (Hamilton, 1982; Porter et al., 1983). In Denali National Park, the late Wisconsin (McKinley Park (MP) I) terminal moraine was deposited between $21.4 \pm 0.7$ and $20.6 \pm 0.5 \mathrm{ka}$ (Ten Brink and Waythomas, 1985; Werner et al., 1993). Three younger phases are constrained between $20.6 \pm 0.5$ and $19.9 \pm 0.3 \mathrm{ka}$ (MP II; Werner et al., 1993; Child, 1995), $15.1 \pm 0.7$ and $12.3 \pm 0.5 \mathrm{ka}$ (MP III; Child, 1995; Ten Brink and Waythomas, 1985) and $12.3 \pm 0.5$ and $11.0 \pm 0.2 \mathrm{ka}$ (MP IV; Ten Brink and Waythomas, 1985).

Recent ${ }^{10}$ Be exposure dating (Dortch, 2006) provides additional ages on the late Wisconsin moraines, including landforms of Riley Creek age in the lower Nenana River valley (Fig. 4) (equivalent to MP deposits in Denali National Park and Donnelly deposits in the Delta River valley; Fig. 3). Landforms of the Riley 1 (oldest) and Riley 2 glaciations produced a wide distribution of ${ }^{10} \mathrm{Be}$ ages, ranging between 61 and $8 \mathrm{ka}$. Deposits of the Carlo glaciation (youngest) produced a tighter cluster of ages between 19 and $17.2 \pm 1.3 \mathrm{ka}$. Dortch (2006) also dated late Wisconsin landforms in the upper portion of the Nenana River drainage basin. Thirteen erratics from the Reindeer Hills, a massif that protrudes from the upper Nenana River lowland, average $16.6 \pm 2.0 \mathrm{ka}$. A group of young erratics from the highest elevations of the massif cluster around $15.5 \pm 0.8 \mathrm{ka} \quad(n=5)$, which may record the timing of deglaciation of the summit by local glaciers. If so, then the lower valley walls of the massif were deglaciated between 19 and $17.3 \pm 2.3 \mathrm{ka}$ (Dortch, 2006).
In the Swift River valley of the western Alaska Range (Fig. 4), four ${ }^{10} \mathrm{Be}$ ages from the largest $(2-6 \mathrm{~m}$ high) and most stable moraine boulders that we have seen in Alaska constrain the age of the late Wisconsin (Farewell II equivalent) terminal moraine to between 21 and $19.6 \pm 0.9$ ka (Briner et al., 2005). In the central Alaska Range, moraines offset by prominent faults in five valleys were recently dated with ${ }^{10}$ Be to determine slip rates (Matmon et al., 2006). The moraines are located well upvalley from late Wisconsin terminal moraines, and their ages can be divided into an older age group of 17-16 ka (two moraines) and a younger group of 13-12 ka (three moraines). All moraines were dated by at least three ${ }^{10} \mathrm{Be}$ ages, and two of the younger moraines were particularly well dated. Both are within $2 \mathrm{~km}$ of extant glacier snouts; one is 11.7 to $11.0 \pm 0.5 \mathrm{ka}$ (seven samples) and the other 14.2 to $12.2 \pm 1.3 \mathrm{ka}$ (11 samples).

To summarise the Late Pleistocene glacial chronology in the Alaska Range, ${ }^{10}$ Be ages from two sites indicate that moraines of the penultimate glaciation stabilised between 60 and 55, and tephrostratigraphy constrains one penultimate moraine to $>140 \mathrm{ka}$. The ${ }^{14} \mathrm{C}$ and ${ }^{10} \mathrm{Be}$ ages suggest that the late Wisconsin terminal moraines were deposited 21-20 ka, followed by retreat to an ice margin between 19 and $17 \mathrm{ka}$. Later readvances seem to have occurred between 17 and $16 \mathrm{ka}$, and 14 and $12 \mathrm{ka}$. Finally, the latest Pleistocene advance is dated by ${ }^{14} \mathrm{C}$ in McKinley Park and by ${ }^{10} \mathrm{Be}$ in the eastern Alaska Range to between 12 and $11 \mathrm{ka}$.

\section{Ahklun Mountains}

The Ahklun Mountains, a $150 \times 200 \mathrm{~km}$ range in southwestern Alaska (Fig. 1), were covered by the largest ice mass in western Alaska. The range has been the focus of Quaternary research in the last decade, and a detailed mid and late Quaternary glacial history has emerged through surficial mapping, and stratigraphic and lake core studies, coupled with a suite of geochronological methods (Kaufman et al., 1996; Briner and Kaufman, 2000; Briner et al., 2001; Manley et al., 2001; Kaufman et al., 2001a,b; Briner et al., 2002; Kaufman et al., 2003; Axford and Kaufman, 2004; Levy et al., 2004). During the Late Pleistocene, the Ahklun Mountains hosted an ice cap over its east-central spine that expanded radially, extending farther to the south and west than to the north and east (Fig. 5); isolated alpine glaciers occupied the highest valleys beyond the ice cap margin. In most valleys, Late Pleistocene drift comprises several moraine belts formed by outlet glaciers of the central ice cap (Manley et al., 2001).

The penultimate drift (deposited during the locally termed Arolik Lake glaciation; Fig. 3) is dated in several locations across the range. In the southern Ahklun Mountains, Kaufman et al. (2001a) report a thermoluminescence (TL) age of $70 \pm 10 \mathrm{ka}$ on lava-baked sediment that underlies penultimate drift and provides a maximum-limiting age on the glaciation. Manley et al. (2001) report a minimum ${ }^{14} \mathrm{C}$ age of $39.9 \mathrm{ka}$ on organic material that overlies Arolik Lake drift. In the western Ahklun Mountains, Briner et al. (2001) used four ${ }^{36} \mathrm{Cl}$ exposure ages on erratic boulders deposited in the Goodnews River valley to constrain the age of the Arolik Lake glaciation to between 56 and $53.8 \pm 2.6 \mathrm{ka}$. Thus, the ${ }^{36} \mathrm{Cl}$ ages on boulders deposited during the Arolik Lake glaciation fit well between the $\mathrm{TL}$ maximum age of $70 \pm 10 \mathrm{ka}$ and the ${ }^{14} \mathrm{C}$ minimum age of $40 \mathrm{ka}$. These ages are in general agreement with amino acid and luminescence ages from glacial-estuarine sediments of the penultimate glaciation in the Bristol Bay lowland (Fig. 4), which ranged between 90 and $55 \mathrm{ka}$ (Kaufman et al., 1996). 


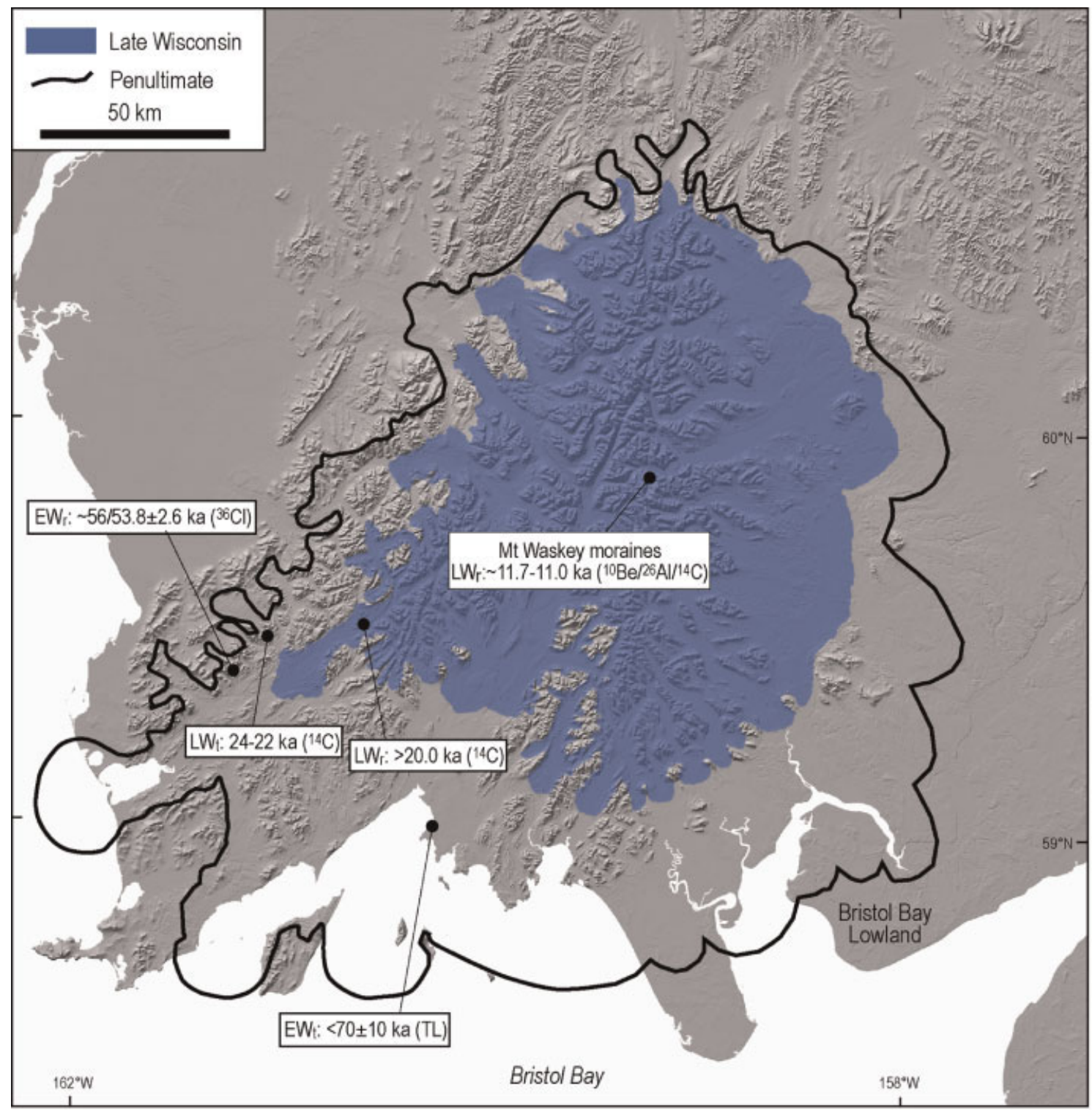

Figure 5 Ahklun Mountains showing the extent of glaciers during the penultimate and late Wisconsin glaciations with locations of key ages. Map area shown in Fig. 1; explanation of map abbreviations in Fig. 2. This figure is available in colour online at www.interscience.wiley.com/journal/jqs

Collectively, these ages indicate a major glaciation in the Ahklun Mountains roughly coincident with MIS 4; in the Bristol Bay lowlands, however, we cannot exclude the possibility that the advance culminated late during MIS 5.

The age of the late Wisconsin drift (deposited during the locally termed Klak Creek glaciation; Fig. 3) is known from several ${ }^{14} \mathrm{C}$ determinations from hummocky moraine belts and associated deposits in the western Ahklun Mountains. In the southwestern Ahklun Mountains, the late Wisconsin glaciation is well dated by ${ }^{14} \mathrm{C}$ ages that bracket the sediment from a glacier-dammed lake that overflowed into Arolik Lake. The arrival to, and the retreat from, the maximum position reached by the Goodnews River valley outlet glacier are tightly constrained in lake sediment cores to between 24 and $22 \mathrm{ka}$ (Kaufman et al., 2003). Four ${ }^{36} \mathrm{Cl}$ ages from boulders on the terminal moraine in a nearby valley range between 21 and $19.6 \pm 1.5 \mathrm{ka}$ (Briner et al., 2001). Manley et al. (2001) report a minimum ${ }^{14} \mathrm{C}$ age of $19.9 \pm 0.3 \mathrm{ka}$ for next-to-oldest hummocky drift belt deposited during the late Wisconsin. Thus, following the deposition of the terminal moraine between 24 and $22 \mathrm{ka}$, ice in the Ahklun Mountains deposited a second moraine just before $20 \mathrm{ka}$.
Following several minor fluctuations and extensive ice stagnation, late Wisconsin glaciation in the Ahklun Mountains concluded with a Lateglacial readvance represented by several small, single-crested vegetated moraines a few kilometres downvalley of extant glaciers in some, but not all, of the highest valleys in the range. In the Mt Waskey massif (Fig. 5), a sediment core that penetrated to glacial-lacustrine mud in Waskey Lake has a basal ${ }^{14} \mathrm{C}$ age of $11.0 \pm 0.2 \mathrm{ka}$ (Levy et al., 2004). The lake is impounded by the Mt Waskey moraine. Briner et al. (2002) obtained exposure ages on nine granodiorite boulders (five ${ }^{10} \mathrm{Be}$ ages, two ${ }^{26} \mathrm{Al}$ ages, and two ${ }^{10} \mathrm{Be} /{ }^{26} \mathrm{Al}$ average ages) from this and from morphostratigraphically similar moraines in a neighbouring valley. Excluding two old outliers, the moraines stabilised between 11.7 and $10.6 \pm 0.8 \mathrm{ka}$. Because the basal age from Waskey Lake suggests that the moraines are older than $11 \mathrm{ka}$, the best estimate for their stabilisation age is between 11.7 and $11 \mathrm{ka}$.

Late Wisconsin ELAs have been estimated from reconstructed cirque and valley glaciers surrounding, and independent of, the Ahklun Mountains ice cap using the accumulation area ratio method (Manley et al., 1997). These ELAs range from $600-800 \mathrm{~m}$ a.s.l. in the north to $280-480$ in the south-west, and 
average $540 \pm 140 \mathrm{~m}$ a.s.I., roughly $200-400 \mathrm{~m}$ lower than the ELAs of modern glaciers in the highest portion of the Ahklun Mountains. The gradient of the ELAs sloped 1.7 to $2.5 \mathrm{~m} \mathrm{~km}^{-1}$ toward the south-west during the late Wisconsin (Manley et al., 1997). In the western Ahklun Mountains, several early Wisconsin valley glaciers have reconstructed ELAs that are 50-90 m lower than late Wisconsin ELAs (Briner and Kaufman, 2000).

\section{Discussion}

\section{Temporal and spatial patterns of Late Pleistocene glaciation in Alaska}

The application of new geochronological methods in Alaska has greatly improved the understanding of the timing of mountain glacier fluctuations during the Late Pleistocene. This is especially true for the penultimate glacier advance, which for decades was suspected to post-date the last interglaciation (Hamilton, 1986b, 1994, 2001). The penultimate advance culminated between 60 and $50 \mathrm{ka}$, based on cosmogenic exposure ages of moraine boulders in three valleys from sites up to $800 \mathrm{~km}$ apart (Fig. 6; Table 1). An alternative interpretation of these cosmogenic exposure ages is that they represent farminimum ages for an older termination of the penultimate advance, perhaps due to either moraine degradation or boulder surface erosion prohibiting older ages. We reject this alternative explanation for several reasons. First, there are many cosmogenic exposure ages on Alaskan moraine boulders that pre-date the 60-50 ka interval (Briner et al., 2005). Second, there are several moraines that date to the 60-50 ka interval from across Alaska, including new data from the Yukon Territory (see below). Finally, if the penultimate advance terminated earlier (e.g., MIS 6 or MIS 5), there should be a skewed distribution of ages older than the 60-50 ka interval. Thus, we conclude with some certainty that the largest advance of mountain glaciers during the Late Pleistocene occurred prior to the global LGM, and likely culminated near the end of MIS 4 or early during MIS 3.

Although not yet dated in the Brooks Range, penultimate moraines there are likely of similar age, because they post-date the Old Crow tephra (Hamilton, 2001). Penultimate drift in some locations might pre-date the Late Pleistocene, such as in the Delta River valley (Begét and Keskinen, 2003). In other valleys of the north Alaska Range, however, penultimate drift is Late Pleistocene age (Dortch, 2006), in agreement with ages from elsewhere in the state, suggesting that the relative extent of glacier advances in the Delta River valley may have been anomalous. A pulse of loess deposition in the Tanana River valley (Begét, 2001) that appears to coincide with MIS 4 supports the notion of a regionally significant early Wisconsin glacier advance in the north Alaska Range (Fig. 6). The discrepancy between the MIS 6 age of the Delta Moraine and Late Pleistocene age assignments for penultimate moraines elsewhere could be reconciled by mapping by T. Hamilton (pers. comm.) that reveals a moraine/outwash sequence between the Delta and Donnelly (LGM) moraines. The regional morphostratigraphy may be further complicated by active Late Pleistocene tectonism along the north flank of the central Alaska Range (Matmon et al., 2006).

New chronologies have also improved the ages of mountain glacier fluctuations during the late Wisconsin. Although still sparse, the chronologies across Alaska show some pattern in timing of the maximum extent of mountain glaciers during MIS 2 (Table 1). Many of these chronologies are based on cosmogenic exposure ages of moraine boulders, which likely date the timing of moraine stabilisation upon glacier retreat (Briner et al., 2005). In northern Alaska, glaciers retreated from their late Wisconsin terminal moraines by $25 \mathrm{ka}$, compared to 22-20 ka in central and southern portions of the state. The age of the advance phase of late Wisconsin glacier expansion is constrained in very few places: in Denali National Park in the Alaska Range, glaciers neared their late Wisconsin limit around $22 \mathrm{ka}$, and around $24 \mathrm{ka}$ at Arolik Lake in the Ahklun Mountains. Thus, the retreat of Brooks Range glaciers seems to have occurred several thousand years before the advance of glaciers in central and southern Alaska during MIS 2.
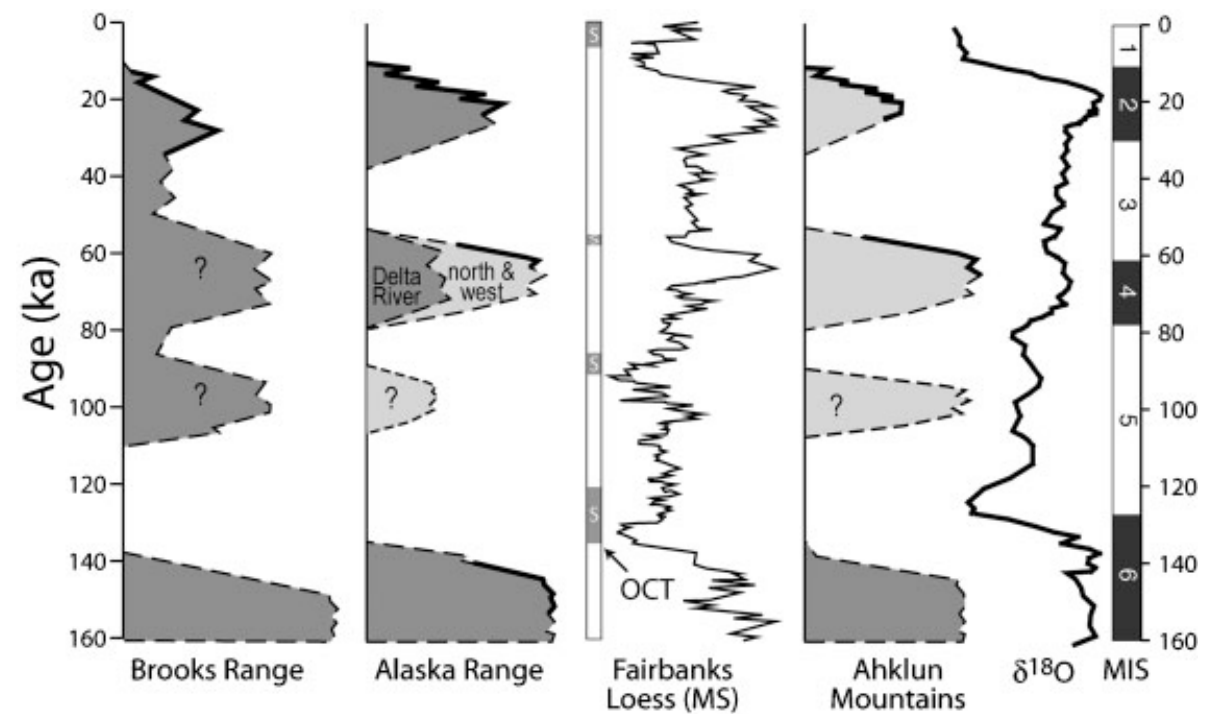

Figure 6 Time-distance diagrams for glaciers in the three areas discussed in the text (see text for discussion of individual sequences and data sources). The magnetic susceptibility (MS) profile for Fairbanks loess (Begét, 2001) and the position of soils (S) and the Old Crow tephra (OCT) is shown for comparison. The global marine oxygen isotope record (Martinson et al., 1987) and marine isotope stages (MIS) are shown for reference. Solid lines, securely dated glacier extent; dashed lines, approximate and subjective glacier extent. Note that the deglaciation phase is only a solid line where the age is constrained by cosmogenic exposure dating 
Table 1 Summary of penultimate and late Wisconsin moraines dated in Alaska by cosmogenic exposure dating

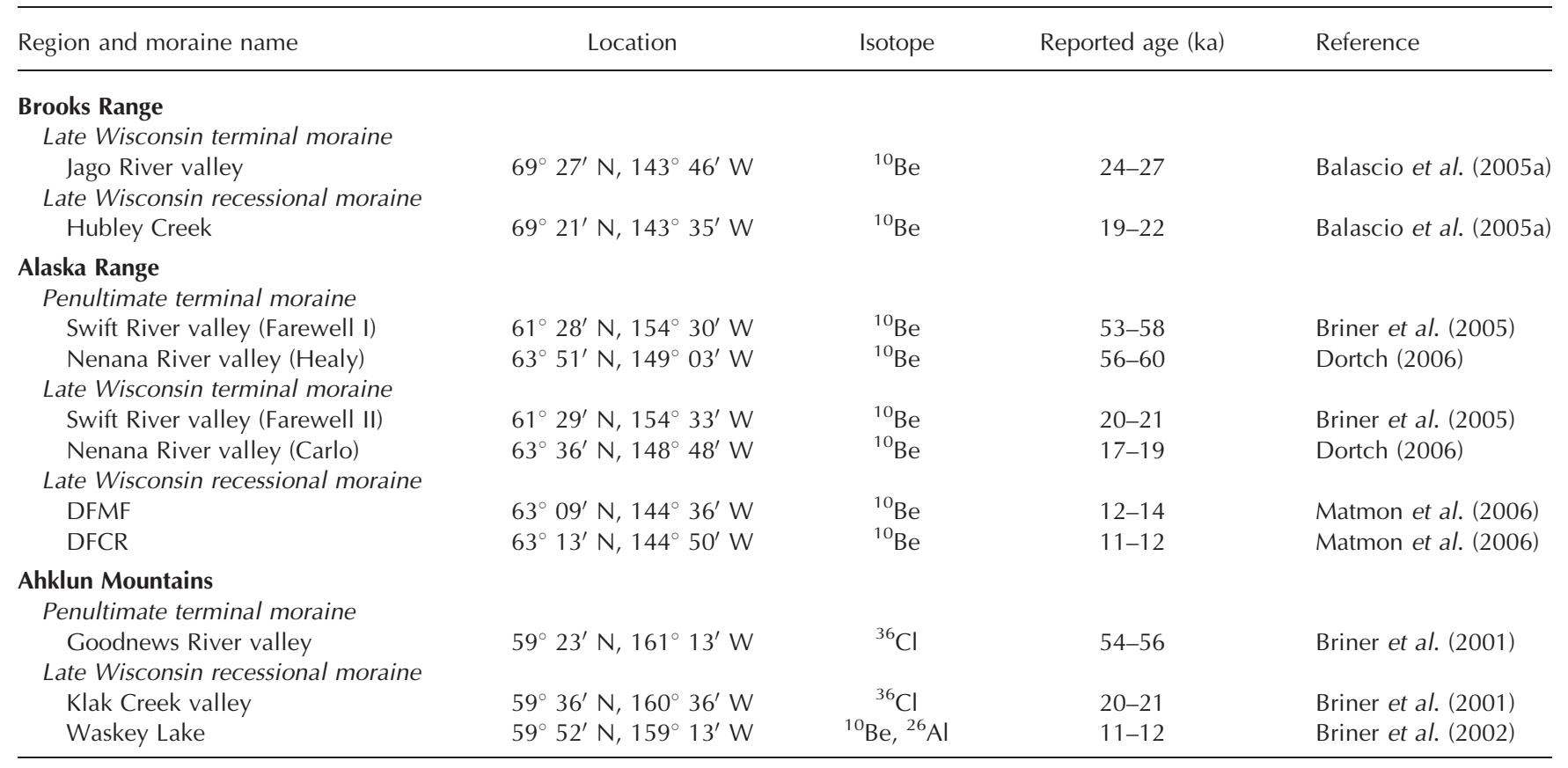

Drift deposited during MIS 2 has been dated throughout Alaska in areas other than the three mountain ranges discussed here. Although dozens of limiting radiocarbon ages loosely constrain moraines to MIS 2 (e.g. Hamilton, 1994; Mann and Hamilton, 1995), only a few additional localities have tight age control. On the upper Alaska Peninsula, radiocarbon ages from river bluffs constrain MIS 2 advances to between ca. 30 and $14.8 \mathrm{ka}$ (Stilwell and Kaufman, 1996). On nearby Kodiak Island, the maximum MIS 2 advance occurred between ca. 26 and $17.8 \mathrm{ka}$ (Mann and Peteet, 1994). Outlet glaciers that filled Cook Inlet, south-central Alaska, retreated from their MIS 2 maximum positions by ca. 19.4 ka (Reger and Pinney, 1996).

Following the maximum phase of the late Wisconsin, glaciers across the state constructed end moraines during subsequent periods of stabilisation or readvance. Although most glaciated valleys across Alaska contain multiple moraines, few have been dated, hampering state-wide comparisons; however, glaciers in many valleys built sizeable moraines near terminal moraines shortly following their initial retreat. In the Ahklun Mountains, for example, prominent end moraines were deposited about $20 \mathrm{ka}$, and in the Alaska Range end moraines post-dating the terminal moraine formed around $19 \mathrm{ka}$. In both cases, glaciers stabilised near their former limits for one or two thousand years following the maximum phase.

Of particular interest is the evidence for a glacier readvance in Alaska concurrent with the North Atlantic Younger Dryas event. In the Ahklun Mountains, a Lateglacial advance culminated $11.7-11 \mathrm{ka}$ in some of the highest tributary valleys (Briner et al., 2002). In the northern Alaska Range, the MP-IV advance is dated by ${ }^{14} \mathrm{C}$ to between 12.3 and $11 \mathrm{ka}$ (Ten Brink and Waythomas, 1985), the same age as one of the moraines along the northern range front dated by ${ }^{10} \mathrm{Be}$ to between 11.7 and $11 \mathrm{ka}$ (Matmon et al., 2006). A ${ }^{14} \mathrm{C}$ age on sediment overlapping a moraine in the Kenai Mountains, south-central Alaska, might correlate with the Younger Dryas (Reger et al., 1995), and other proxy climate records from Alaska clearly attest to a climatic reversal during the Younger Dryas (e.g. Hu et al., 2006). Nonetheless, widespread evidence for a glacier readvance during the Younger Dryas has yet to be revealed across Alaska. The youngest Lateglacial readvance in the Brooks Range, for example, occurred prior to the Younger
Dryas, between 15 and 13 ka (Hamilton, 2003). Thus, glaciers across the state register readvances during the last glacialinterglacial transition, but only in a few places can they be considered a candidate for a glacier advance during the Younger Dryas.

\section{Correlations with adjacent regions}

Late Pleistocene mountain glacier chronologies are emerging worldwide, including in regions adjacent to Alaska, known collectively as Beringia. In northeastern Siberia, Gualtieri et al. (2000) report $16{ }^{36} \mathrm{Cl}$ ages, and Brigham-Grette et al. (2003) report $12{ }^{36} \mathrm{Cl}$ ages from two mountain ranges (Pekulney and Koryak Mountains) where the glacial morphostratigraphy is similar to Alaska. The best-dated early Wisconsin glacial feature in northeastern Russia is glacially scoured bedrock with ${ }^{36} \mathrm{Cl}$ ages ranging between 69 and $56 \mathrm{ka}$, although the bedrock surface exhibited evidence of erosion (Brigham-Grette et al., 2003). Although ages on late Wisconsin drift are scattered, they indicate that terminal and younger end moraines were deposited between 24 and $16 \mathrm{ka}$. An outwash terrace graded to an end moraine behind the terminal late Wisconsin moraine, thought to be close in age to the terminal moraine, is dated by a cluster of three ${ }^{14} \mathrm{C}$ ages from organics within the outwash that average $18.7 \pm 0.5 \mathrm{ka}$.

In the western Yukon Territory, Canada, ${ }^{10}$ Be ages have recently been obtained from penultimate drift deposited by a lobe of the Cordilleran Ice Sheet that emanated from the St Elias and Coast mountains. Four ages on $1.5-3.7 \mathrm{~m}$ high erratics range between 54 and $53.3 \pm 1.3 \mathrm{ka}$, providing the first evidence that the penultimate drift in western Yukon (=Gladstone glaciation) dates to MIS 4 or early during MIS 3 (Ward et al., 2007). In contrast, penultimate drift derived from the Selwyn lobe of the Cordilleran Ice Sheet in central Yukon (=Reid glaciation) is younger than the Sheep Creek tephra (Westgate et al., 2001), recently discovered to be multiple tephras dating to as young as $80 \mathrm{ka}$ (Westgate et al., 2008) and older than radiometrically dated basalt (Huscroft et al., 2004), and is correlated with MIS 8 age. 
Given the few well-dated records of the penultimate glaciation in Beringia, it is difficult to characterise temporal patterns across the broader region. Although the penultimate drift dated from sites spanning $800 \mathrm{~km}$ across Beringia appears to coincide with MIS 4 or early MIS 3, the extent to which glacier maxima were attained synchronously from place to place is not known. A similar conclusion was reached based on the frequency and source of ice-rafted detritus (IRD) in the North Pacific; although the mass accumulation rate of IRD was high, if not higher, during MIS 4 than MIS 2 (Hewitt et al., 1997), significant variations in source and timing of IRD suggest regional controls on iceberg input (St John and Krissek, 1999). The maximum MIS 2 advance seems to have occurred earliest in arctic Alaska (27-25 ka) and later (24-20 ka) in regions more strongly influenced by the Pacific Ocean.

\section{Palaeoclimate controls}

The only comprehensive state-wide compilation of snowline estimates for the late Wisconsin was based on cirque-floor altitudes (Péwé, 1975). These show a spatial pattern similar to the modern snowline, namely a south-west moisture source and prominent orographic effects on the windward and leeward side of major mountain ranges. Studies of individual mountain ranges indicate that glacier ELAs were generally 300-600 m lower across Alaska during the LGM (Hamilton and Porter, 1975; Kaufman and Hopkins, 1986; Mann and Peteet, 1994; Stilwell and Kaufman, 1996; Manley et al., 1997; Briner and Kaufman, 2000; Balascio et al., 2005b). This relatively minor ELA lowering contrasts with a more typical mid-latitude value of $1000 \mathrm{~m}$ (Broecker and Denton, 1990) and has long been attributed to arid conditions related to increased continentality resulting from the emergence of the Bering-Chukchi platform during eustatic sea-level lowering (e.g. Hopkins, 1982). Moisture sources may have been further restricted as sea-ice cover expanded over the Aleutian basin in the southern Bering Sea to the south-west (Sancetta et al., 1984) and the Beaufort Sea in the north (Phillips and Grantz, 1997). Farther south-west, in the northwestern Pacific, however, more recent multi-proxy evidence indicates that sea-surface temperature was not significantly lower at $20 \mathrm{ka}$ compared with the Holocene (Sarnthein et al., 2006). Similarly, in the Gulf of Alaska, dinoflagellate cyst assemblages indicate little change in temperature and sea-ice cover (de Vernal et al., 2005). On land, cold and dry conditions during the late Wisconsin are inferred from pollen records, which reveal a sparsely vegetated landscape dominated by herbaceous tundra across Alaska (e.g. Anderson et al., 2004). Hydrological-balance models informed by lake-level evidence indicate considerable reduction in effective moisture (Barber and Finney, 2000). Pollen and lake status indicate that, although generally cold and arid, central Beringia may have been slightly more mesic than interior Alaska, and summers may have been warm enough to support poplar trees (Ager, 2003). Fossil insect data from the central Beringia indicate relatively mild LGM temperature depression (Elias, 2001).

The palaeoenvironmental evidence for cold conditions in Alaska contrasts with results of palaeoclimate modelling for the LGM. General circulation models (GCMs) consistently show enhanced southwesterly flow of warm air into Alaska (e.g. Kutzbach et al., 1998). Recent simulations using Community Climate System Model version 3 (CCSM3) clearly depict significantly warmer-than-modern (pre-industrial) annual temperature across Alaska during the LGM, although the simulated warming diminishes with the height of the Laurentide Ice Sheet (Otto-Bliesner et al., 2006). Seasonally resolved output from CCSM3 (B. Otto-Bliesner, pers. comm., 2007) shows that the warming occurs during both winter and summer months. The model also shows decreased precipitation across Alaska, except for the Gulf of Alaska. The models are consistent with the palaeo-glacier evidence that clearly attests to limited ice extent in Alaska compared with most northern high-latitude regions, and with a southwesterly moisture source for glaciers in the Brooks Range (Balascio et al., 2005b). On the other hand, the models are inconsistent with findings of northeasterly winds in northern Alaska during the LGM (e.g. Muhs et al., 2003). Regardless, we suggest that glacier expansion in Alaska was limited not only by decreased precipitation, which is well known from the palaeoenvironmental record, but also by a lack of significant summer cooling during the LGM.

The growing evidence for maximum Late Pleistocene glaciation prior to MIS 2 in Alaska summarised here contrasts with the global marine oxygen isotope record, which features maximum ice volume late during the last glacial cycle. Many mountain glaciers at lower latitudes in North America attained their maximum extent during MIS 2 (Gillespie and Molnar, 1995; Pierce, 2004). Previous studies have emphasised evidence for 'out-of-phase' glaciations in Beringia (e.g. Brigham-Grette, 2001; Kaufman et al., 2001a). Glaciers in northeastern Siberia and western Alaska expanded onto the continental shelf several times during the Middle Pleistocene. They deposited glacial-marine sediment hundreds of kilometres inboard the shelf edge, implying that eustatic sea level was high during the maximum phase, and supporting the hypothesis that large glacier expansions in Alaska require a proximal source of moisture. Sea level probably fell below the shelf break to expose the Bering-Chukchi platform following substage $5 \mathrm{a}$, and the transition between MIS $5 \mathrm{a}$ and 4 , around 75 ka (based on orbitally tuned global marine oxygen isotopes; Martinson et al., 1987), has been suggested as a candidate for extensive glacier growth in Beringia (Brigham-Grette, 2001). Eustatic sea level rose again during MIS 3. Dated coral reefs in the Pacific and other evidence reviewed by Cabioch and Ayliffe (2001) indicate a transgression to within $30-60 \mathrm{~m}$ of present, seemingly high enough to inundate a large portion of the continental shelf in central Beringia. This proximal moisture source would have enhanced moisture availability during MIS 3. Thus, the emergence of the Bering shelf during MIS 4 and associated aridity is in contrast to geochronological evidence that the penultimate advance culminated at the end of MIS 4. During MIS 2 moisture availability decreased as sea level fell from the shelf break. In addition, GCM simulations show that, as the Laurentide Ice Sheet grew, the Aleutian low-pressure system strengthened (Otto-Bliesner et al., 2006). The instrumental data demonstrate that a stronger, eastward-shifted low steers storms away from western Alaska and into the Gulf of Alaska (Rodionov et al., 2005). Increased winter storminess would have nourished the Cordilleran Ice Sheet over the coastal ranges. The higher ice would have enhanced the orographic barrier and narrowed passages for low-level moisture transport, further depleting moisture in interior Alaska during the LGM.

\section{Summary and conclusion}

This paper focused on the most robust Late Pleistocene mountain glacial chronologies currently available in Alaska. New cosmogenic exposure ages combined with ${ }^{14} \mathrm{C}$, luminescence, and tephra-based ages have improved the geochronological control on the glacial history of Alaska. 
Although previously suspected to be early Wisconsin in age (Hamilton, 1994), new numerical ages place the culmination of the penultimate glaciation in Beringia into MIS 4 or early MIS 3. There is widespread evidence for a significant advance in northern Eurasia that similarly culminated between 60 and $50 \mathrm{ka}$ (Svendsen et al., 2004). During the late Wisconsin, glaciers appeared to have deposited terminal moraines earlier (27-25 ka) in arctic Alaska than in southern Alaska (24-20 ka). Glaciers remained close to their maximum extent for thousands of years following the local glacial maximum. Although their ages are generally not well constrained, the numerous end moraines upvalley of terminal moraines document the response of glaciers to climate change through the Lateglacial period. Finally, glacier advances in a few valleys may be correlative with the Younger Dryas event.

Among the most notable features of Late Pleistocene glaciation in Alaska are: (1) more extensive glaciation during MIS 4/3 than during MIS 2; (2) relatively restricted glacier extent, requiring only modest $(300-600 \mathrm{~m})$ ELA lowering compared to the mid-latitudes; and (3) an earlier MIS 2 maximum extent in the arctic- versus Pacific-dominated portions of the state. These features likely relate to temporal and spatial patterns of moisture availability, with more moisture available during MIS 4/3 than during MIS 2. In addition, relatively mild summers may have combined with arid conditions during MIS 2 to limit glacier expansion. Similar to temporal patterns elsewhere, such as in the Andes Mountains where the maximum MIS 2 glaciation coincided with the global LGM in the south (Kaplan et al., 2004) but pre-dated it in the north (Smith et al., 2005), the timing of peak MIS 2 glaciation in Alaska differed by several thousand years. Glaciers in Alaska probably retreated from their terminal MIS 2 limit prior to ca. 19-17 ka, the interval of common mid-latitude glacier retreat in both hemispheres recently recognized by Schaefer et al. (2006).

We have focused on the few areas where the ages of mountain-glacier moraine sequences are reasonably well known. For these, the prominent penultimate advance has been dated to within the last glaciation, and the timing of the maximum phase of the MIS 2 glaciation is secure. In many areas of the state, however, the glacial geology has been studied at the reconnaissance level only, and numerical age control is lacking. In the Brooks Range in arctic Alaska, for example, the penultimate drift is undated. Although recent efforts have revealed a systematic temporal pattern to the deposition of MIS 2 terminal moraines across the state, age control is sparse on the numerous moraines younger than the terminal moraine, including those deposited during the Lateglacial period. As new information on the ages and extent of glacier fluctuations continues to be generated, Alaska's alpine glacier record combined with glacier-climate models will lead to improved and quantitative understanding of the palaeoclimate controls on glaciation.

Acknowledgements Our glacial-geological research in Alaska was supported by NSF grants OPP-9977972 and OPP-9977974 to DSK. This compilation benefited from stimulating discussions with many people, including Yarrow Axford, Nick Balascio, Jason Dortch, Thomas Hamilton, William Manley, Al Werner and the entire INQUA Mountain Glacier working group. We are grateful for enlightening reviews from Thomas Hamilton and one anonymous reviewer.

\section{References}

Ager TA. 2003. Late Quaternary vegetation and climate history of the central Bering land bridge from St Michael Island, western Alaska. Quaternary Research 60: 19-32.
Anderson PM, Edwards ME, Brubaker LB. 2004. Results and paleoclimatic implications of 35 years of paleoecological research in Alaska,. in The Quaternary Period in the United States: Developments in Quaternary Science, Vol. 1, Gillespie AR, Porter SC, Atwater BF (eds). Elsevier: Amsterdam; 427-440.

Axford YL, Kaufman DS. 2004. Late glacial and Holocene vegetation and glacier fluctuations at Little Swift Lake, southwestern Alaska. Arctic, Antarctic, and Alpine Research 36: 139-146.

Balascio NL, Kaufman DS, Briner JP, Manley WF. 2005a. Late Pleistocene glacial geology of the Okpilak-Kongakut Rivers Region, northeastern Brooks Range, Alaska. Arctic, Antarctic, and Alpine Research 37: 416-424.

Balascio NL, Kaufman DS, Manley WF. 2005b. Equilibrium-line altitudes during the Last Glacial Maximum across the Brooks Range, Alaska. Journal of Quaternary Science 20: 821-838.

Barber VA, Finney BP. 2000. Late Quaternary paleoclimatic reconstructions from interior Alaska based on paleolake-level data and hydrologic models. Journal of Paleolimnology 24: 29-41.

Begét JE. 2001. Continuous Late Quaternary proxy climate records from loess in Beringia. Quaternary Science Reviews 20: 499-507.

Begét JE, Keskinen MJ. 2003. Trace-element geochemistry of individual glass shards of the Old Crow tephra and the age of the Delta glaciation, central Alaska. Quaternary Research 60: 63-69.

Brigham-Grette J. 2001. New perspectives on Beringian Quaternary paleogeography, stratigraphy and glacial history. Quaternary Science Reviews 20: 15-24.

Brigham-Grette J, Gualtieri LM, Glushkova OY, Hamilton TD, Mostoller D, Kotov A. 2003. Chlorine-36 and C-14 chronology support a limited last glacial maximum across central Chukotka, northeastern Siberia, and no Beringian ice sheet. Quaternary Research 59: 386398.

Briner JP, Kaufman DS. 2000. Late Pleistocene glaciation of the southwestern Ahklun Mountains, Alaska. Quaternary Research 53: 13-22.

Briner JP, Swanson TW, Caffee M. 2001. Late Pleistocene cosmogenic Cl-36 glacial chronology of the southwestern Ahklun Mountains, Alaska. Quaternary Research 56: 148-154.

Briner JP, Kaufman DS, Werner A, Caffee M, Levy L, Manley WF Kaplan MR, Finkel RC. 2002. Glacier readvance during the late glacial (Younger Dryas?) in the Ahklun Mountains, southwestern Alaska. Geology 30: 679-682.

Briner JP, Kaufman DS, Manley WF, Finkel RC, Caffee MW. 2005. Cosmogenic exposure dating of late Pleistocene moraine stabilization in Alaska. Geological Society of America Bulletin 117: 1108-1120.

Broecker WS, Denton GH. 1990. The role of ocean-atmosphere reorganizations in glacial cycles. Quaternary Science Reviews 9: 305-343.

Cabioch G, Ayliffe LK. 2001. Raised coral terraces at Malakula, Vanuatu, southwest Pacific indicate high sea level during marine isotope stage 3. Quaternary Research 56: 357-365.

Calkin PE, Ellis JM. 1980. A lichenometric dating curve and its application to Holocene glacier studies in the Central Brooks Range, Alaska. Arctic and Alpine Research 12: 245-264.

Child JC. 1995. A late Wisconsinan lacustrine record of environmental change in the Wonder Lake area, Denali National Park and Preserve, AK. Master's thesis, University of Massachusetts.

de Vernal A, Eynaud F, Henry M, Hillaire-Marcel C, Londeix L, Mangin S, Matthiessen J, Marret F, Radi T, Rochon A, Solignac S, Turon J-L. 2005. Reconstruction of sea-surface conditions at middle to high latitudes of the Northern Hemisphere during the Last Glacial Maximum (LGM) based on dinoflagellate cyst assemblages. Quaternary Science Reviews 24: 897-924.

Dortch J. 2006. Defining the timing of glaciation in the central Alaska Range using terrestrial cosmogenic nuclide and optically stimulated luminescence dating of moraines and terraces. Master's thesis, University of Cincinnati.

Dyke AS, Andrews JT, Clark PU, England JH, Miller GH, Shaw J, Veillette JJ. 2002. The Laurentide and Innuitian Ice Sheets during the Last Glacial Maximum. Quaternary Science Reviews 21: 9-31.

Elias SA. 2001. Beringian paleoecology: results from the 1997 workshop. Quaternary Science Reviews 20: 7-13.

Gillespie A, Molnar P. 1995. Asynchronous maximum advances of mountain and continental glaciers. Reviews of Geophysics 33: $311-$ 364. 
Gualtieri L, Glushkova O, Brigham-Grette J. 2000. Evidence for restricted ice extent during the last glacial maximum in the Koryak Mountains of Chukotka, far eastern Russia. Geological Society of America Bulletin 112: 1106-1118.

Hamilton TD. 1982. A late Pleistocene glacial chronology for the southern Brooks Range: stratigraphic record and regional significance. Geological Society of America Bulletin 93: 700-716.

Hamilton TD. 1986a. Late Cenozoic glaciation of the central Brooks Range. In Glaciation in Alaska: The geologic record, Hamilton TD, Reed KM, Thorson RM (eds). Alaska Geological Society: Anchorage; 9-50.

Hamilton TD. 1986b. Correlation of Quaternary glacial deposits in Alaska. Quaternary Science Reviews 5: 171-180.

Hamilton TD. 1994. Late Cenozoic glaciation of Alaska: the geology of Alaska. In The Geology of North America, Vol. G-1, Plafker G, Berg HC (eds). Geological Society of America: Boulder, CO; 813-844.

Hamilton TD. 2001. Quaternary glacial, lacustrine, and fluvial interactions in the western Noatak basin, Northwest Alaska. Quaternary Science Reviews 20: 371-391.

Hamilton TD. 2003. Surficial geology of the Dalton Highway (ItkillikSagavanirktok Rivers) area, southern Arctic Foothills. Professional Report, 121. Alaska Department of Natural Resources/Division Geological and Geophysical Surveys.

Hamilton TD, Porter SC. 1975. Itkillik glaciation in the Brooks Range, northern Alaska. Quaternary Research 5: 471-497.

Hamilton TD, Thorson RM. 1983. The Cordilleran Ice Sheet in Alaska. In Late Quaternary Environments of the United States. The Late Pleistocene, Vol. 1, Porter SC (ed.). University of Minnesota Press: Minneapolis; 38-52.

Hewitt AT, McDonald D, Bornhold BD. 1997. Ice-rafted debris in the North Pacific and correlation to North Atlantic climate events. Geophysical Research Letters 24: 3261-3264.

Hopkins DM. 1982. Aspects of the paleogeography of Beringia during the late Pleistocene. In Paleoecology of Beringia, Hopkins DM, Matthews JV Jr, Schweger CE, Young SB (eds). Academic Press: New York; 3-28.

Hu FS, Nelson DM, Clarke GH, Rühland KM, Huang Y, Kaufman DS, Smol JP. 2006. Abrupt climatic events during the last glacial-interglacial transition in Alaska. Geophysical Research Letters 33: L18708. doi: 10.1029/2006GL027261.

Huscroft CA, Ward BC, Barendregt RW, Jackson LE Jr, Opdyke ND. 2004. Pleistocene volcanic damming of Yukon River and the maximum age of the Reid Glaciation, west-central Yukon. Canadian Journal of Earth Sciences 41: 151-164.

Kaplan MR, Ackert RP, Singer BS, Douglass DC, Kurz MD. 2004. Cosmogenic nuclide chronology of millennial-scale glacial advances during O-isotope stage 2 in Patagonia. Geological Society of America Bulletin 116: 308-321.

Kaufman DS, Hopkins DM. 1986. Glacial history of the Seward Peninsula. In Glaciation in Alaska: The Geologic Record, Hamilton TD, Reed KM, Thorson RM (eds). Alaska Geological Society: Anchorage, AK; 51-78.

Kaufman DS, Manley WF. 2004. Pleistocene Maximum and Late Wisconsin glacier extents across Alaska, USA. In Quaternary Glaciations: Extent and Chronology. Part II: North America, Ehlers J, Gibbard PL (eds). Elsevier: Amsterdam; 9-27.

Kaufman DS, Forman SL, Lea PD, Wobus CW. 1996. Age of pre-lateWisconsin glacial-estuarine sedimentation, Bristol Bay, Alaska. Quaternary Research 45: 59-72.

Kaufman DS, Manley WF, Forman SL, Hu FS, Preece SJ, Westgate JA, Wolfe AP. 2001a. Paleoenvironment; 1; of the last interglacial-toglacial transition, Togiak Bay, southwestern Alaska. Quaternary Research 55: 190-202.

Kaufman DS, Manley WF, Forman SL, Layer P. 2001b. Pre-lateWisconsin glacial history, coastal Ahklun Mountains, southwestern Alaska: new amino acid, thermoluminescence, and ${ }^{40} \mathrm{Ar} /{ }^{39} \mathrm{Ar}$ results. Quaternary Science Reviews 20: 337-352.

Kaufman DS, Hu FS, Briner JP, Werner A, Finney BP, Gregory-Eaves I. 2003. A similar to 33000 year record of environmental change from Arolik Lake, Ahklun Mountains, Alaska, USA. Journal of Paleolimnology 30: 343-362.

Kaufman DS, Porter SC, Gillespie AR. 2004. Quaternary alpine glaciation in Alaska, the Pacific Northwest, Sierra Nevada, and Hawaii. In
The Quaternary Period in the United States: Developments in Quaternary Science, Vol. 1, Gillespie AR, Porter SC, Atwarter BF (eds). Elsevier: Amsterdam; 77-103.

Kline JT, Bundtzen TK. 1986. Two glacial records from west-central Alaska. In Glaciation in Alaska: The Geologic Record, Hamilton TD, Reed KM, Thorson RM (eds). Alaska Geological Society Anchorage 123-150.

Kutzbach JE, Gallimore R, Harrison SP, Behling P, Selin R, Laarif F. 1998. Climate and biome simulations for the past 21000 years. Quaternary Science Reviews 17: 473-506.

Levy LB, Kaufman DS, Werner A. 2004. Holocene glacier fluctuations, Waskey Lake, northeastern Ahklun Mountains, southwestern Alaska. Holocene 14: 185-193.

Manley WF, Kaufman DS. 2002. Alaska PaleoGlacier Atlas, Vol. 1. Institute of Arctic and Alpine Research (INSTAAR), University of Colorado. http://instaar.colorado.edu/QGISL/ak_paleoglacier_atlas.

Manley WF, Kaufman DS, Briner JP. 1997. GIS determination of late Wisconsin equilibrium line altitudes in the Ahklun Mountains of south-western Alaska. Geological Society of America Abstracts with Programs 29: 33.

Manley WF, Kaufman DS, Briner JP. 2001. Late Quaternary glacier fluctuations in the southern Ahklun Mountains, southeast Beringia: soil development, morphometric, and radiocarbon constraints. Quaternary Science Reviews 20: 353-370.

Mann DH, Peteet DM. 1994. Extent and timing of the last glacial maximum in southwestern Alaska. Quaternary Research 42: 136148.

Mann DH, Hamilton TD. 1995. Late Pleistocene and Holocene paleoenvironments of the North Pacific Coast. Quaternary Science Reviews 14: 449-471.

Martinson DG, Pisias NG, Hays JD, Imbrie J, Moore TC Jr, Shackleton NJ. 1987. Age dating and orbital theory of the ice ages: development of a high-resolution 0 to 300 000-year chronostratigraphy. Quaternary Research 27: 1-29.

Matmon A, Schwartz DP, Haeussler PJ, Finkel R, Lienkaemper JJ, Stenner HD, Dawson TE. 2006. Denali fault slip rates and Holocene-late Pleistocene kinematics of central Alaska. Geology 34: 645-648.

Molnia BF. 2007. Late nineteenth to early twenty-first century behavior of Alaskan glaciers as indicators of changing regional climate. Global and Planetary Change 56: 23-56.

Muhs DR, Ager TA, Been J, Bradbury JP, Dean WE. 2003. A late Quaternary record of eolian silt deposition in a maar lake, St Michael Island, western Alaska. Quaternary Research 60: 110-122.

Otto-Bliesner BL, Brandy EC, Clauzet G, Tomas R, Levis S, Kothavala Z. 2006. Last glacial maximum and Holocene climate in CCSM3. Journal of Climate 19: 2526-2544.

Péwé TL. (ed.). 1953. Multiple glaciation in Alaska: a progress report. US Geological Survey Circular 289.

Péwé TL. 1975. The Quaternary geology of Alaska. US Geological Survey Professional Paper 385.

Pierce KL. 2004. Pleistocene glaciations of the Rocky Mountains. In The Quaternary Period in the United States: Developments in Quaternary Science, Vol. 1, Gillespie AR, Porter SC, Atwarter BF (eds). Elsevier: Amsterdam; 63-76.

Phillips RL, Grantz A. 1997. Quaternary history of sea ice and paleoclimate in the Amerasia basin, Arctic Ocean, as recorded in the cyclical strata of the Northwind Ridge. Geological Society of America Bulletin 109: 2-16.

Porter SC, Pierce KL, Hamilton TD. 1983. Late Wisconsin mountain glaciation in the western United States. In Late Quaternary Environments of the United States. The Late Pleistocene, Vol. 1, Porter SC (ed.). University of Minnesota Press: Minneapolis; 71-111.

Reger RD, Pinney DS. 1996. Late Wisconsin glaciation of the Cook Inlet region with emphasis on Kenai lowland and implications for early peopling. In The Anthropology of Cook Inlet: Proceedings from a Symposium, Davis NY, Davis WE (eds). Cook Inlet Historical Society: Anchorage, AK; 5-23.

Reger RD, Combellick RA, Brigham-Grette J. 1995. Update of latest Wisconsin events in the upper Cook Inlet region, south-central Alaska. In Short Notes on Alaska Geology 1995, Combellick RA, Tannian F (eds). Alaska Division of Geological and Geophysical Surveys Professional Report 117; 33-46. 
Rodionov SN, Overland JE, Bond NA. 2005. Spatial and temporal variability of the Aleutian climate. Fisheries Oceanography 14: 3-21.

Sancetta C, Heusser L, Labeyrie L, Naidu AS, Robinson SW. 1984. Wisconsin-Holocene paleoenvironment of the Bering Sea: evidence from diatoms, pollen, oxygen isotopes and clay minerals. Marine Geology 62: 55-68.

Sarnthein M, Kiefer T, Grootes PM, Elderfield H, Erlenkeuser H. 2006. Warming in the far northwestern Pacific promoted pre-Colivs immigration to America during Heinrich event 1. Geology 34: 141-144.

Schaefer JM, Denton GH, Barrell DJA, Ivy-Ochs S, Kubik PW, Andersen BG, Phillips FM, Lowell TV, Schlüchter C. 2006. Near-synchronous interhemispheric termination of the last glacial maximum in midlatitudes. Science 312: 1510-1513.

Smith JA, Seltzer GO, Farber DL, Rodbell DT, Finkel RC. 2005. Early local last glacial maximum in the tropical Andes. Science 308: 678681

Stilwell KB, Kaufman DS. 1996. Late Wisconsin glacial history of the northern Alaska Peninsula, southwestern Alaska, USA. Arctic and Alpine Research 28: 475-487.

St John KEK, Krissek LA. 1999. Regional patterns of Pleistocene icerafted debris flux in the North Pacific. Paleoceanography 14: 653662.

Stuiver M, Reimer PJ. 1993. Extended ${ }^{14} \mathrm{C}$ database and revised CALIB radiocarbon calibration program. Radiocarbon 35: 215-230.

Svendsen JI, Alexanderson H, Astakhov VI, Demidov I, Dowdeswell JA, Funder S, Gataullin V, Henriksen M, Hjort C, Houmark-Nielsen M, Hubberten HW, Ingolfsson $\mathrm{O}$, Jakobsson $\mathrm{M}$, Kjaer $\mathrm{KH}$, Larsen $\mathrm{E}$, Lokrantz H, Lunkka JP, Lysa A, Mangerud J, Matiouchkov A, Murray A, Moller P, Niessen F, Nikolskaya O, Polyak L, Saarnisto M, Siegert C, Siegert MJ, Spielhagen RF, Stein R. 2004. Late Quaternary ice sheet history of northern Eurasia. Quaternary Science Reviews 23: 1229-1271.

Ten Brink NW, Waythomas CF. 1985. Late Wisconsin glacial chronology of the north-central Alaska Range: a regional synthesis and its implications for early human settlements. In North Alaska Range Early Man Project, Powers WR et al. (eds). National Geographic Society Research Reports, National: Geographic Society Washington, DC; 15-32.

Thorson RM. 1986. Late Cenozoic glaciation of the northern Nenana River valley. In Glaciation in Alaska: The geologic record, Hamilton TD, Reed KM, Thorson RM (eds). Alaska Geological Society: Anchorage; 171-192.

Wahrhaftig C. 1958. Quaternary geology of the Nenana River valley and adjacent parts of the Alaska Range. US Geological Survey Professional Paper 293.

Ward BC, Bond JD, Gosse JC. 2007. Evidence for a 55- to 50-ka (early Wisconsin) glaciation of the Cordilleran ice sheet, Yukon Territory, Canada. Quaternary Research 68: 141-150.

Werner A, Wright K, Child J. 1993. Bluff stratigraphy along the McKinley River: a record of late Wisconsin climatic change. Geological Society of America Abstracts with Programs 25: 224.

Westgate JA, Preece SJ, Froese DG, Walter RC, Sandhu A, Schweger CE. 2001. Dating early and middle (Reid) Pleistocene glaciation in central Yukon by tephrochronology. Quaternary Research 56: 335-348.

Westgate JA, Preece SJ, Froese DG, Pearce NJG, Roberts RG, Demuro M, Hart WK, Perkins W. 2008. Changing ideas on the identity and stratigraphic significance of the Sheep Creek tephra beds in Alaska and the Yukon Territory, northwestern North America. Quaternary International 178: 183-209. 